\title{
Video Article \\ Protocol for Dengue Infections in Mosquitoes (A. aegypti) and Infection Phenotype Determination
}

\author{
Suchismita Das ${ }^{1}$, Lindsey Garver ${ }^{1}$, Jose Ruiz Ramirez ${ }^{1}$, Zhiyong $\mathrm{Xi}^{1}$, George Dimopoulos ${ }^{1}$ \\ ${ }^{1}$ Malaria Research Institute, Bloomberg School of Public Health, Johns Hopkins University \\ Correspondence to: George Dimopoulos at gdimopou@jhsph.edu
}

URL: https://www.jove.com/video/220

DOI: doi:10.3791/220

Keywords: Cellular Biology, Issue 5, mosquito, dengue, fever, infectious disease

Date Published: 7/4/2007

Citation: Das, S., Garver, L., Ramirez, J.R., Xi, Z., Dimopoulos, G. Protocol for Dengue Infections in Mosquitoes (A. aegypti) and Infection Phenotype Determination. J. Vis. Exp. (5), e220, doi:10.3791/220 (2007).

\section{Abstract}

The purpose of this procedure is to infect the Aedes mosquito with dengue virus in a laboratory condition and examine the infection level and dynamic of the virus in the mosquito tissues. This protocol is routinely used for studying mosquito-virus interactions, especially for identification of novel host factors that are able to determine vector competence. The entire experiment must be conducted in a BSL2 laboratory. Similar to Plasmodium falciparum infections, proper attire including gloves and lab coat must be worn at all times. After the experiment, all the materials that came in contact with the virus need to be treated with $75 \%$ ethanol and bleached before proceeding with normal washing. All other materials need to be autoclaved before discarding them.

\section{Video Link}

The video component of this article can be found at https://www.jove.com/video/220/

\section{Protocol}

\section{A. Propagate the virus in the $\mathrm{C} 6 / 36$ cell line.}

1. Cells grow to $80 \%$ confluency in $75 \mathrm{~cm}^{2}$ flask;

2. Remove the media with $3-4 \mathrm{ml}$ remaining in the flask;

3. Take $0.5 \mathrm{ml}$ stock virus and add into the above cell with the multiplicity of infection of 1.5 virus particles per cell. Shaking the flask for 15 minutes slowly at the room temperature.

4. Incubate for 45 minutes at $5 \% \mathrm{CO}_{2}$ and $37^{\circ} \mathrm{C}$

5. Add $30 \mathrm{ml}$ media, and incubate for 5 days.

\section{B. Prepare the mixture of virus and blood}

1. Detach the cell with the scraper and transfer the cell and media to the $50 \mathrm{~mL}$ conical tubes;

2. Centrifugate at $800 \mathrm{~g}$ for 10 minutes; collect the supernatant, but leave $1 \mathrm{ml}$ of supernatant with the cell pellet;

3. Freeze the above cell pellet in dry $\mathrm{CO}_{2}$ and then thaw in $37^{\circ} \mathrm{C}$ water bath, repeat two to three times;

4. Centrifugate at $800 \mathrm{~g}$ for 10 minutes, take the supernatant, and combine with the supernatant collected from step 3;

5. Collect whole human blood with the same procedure (step 3 ) for preparation of gametocyte culture to infect Anopheles mosquito with Plasmodium falciparum;

6. Combine the equal amount of the above whole human blood with virus supernatant from step 4 , and add human serum (10\% of the whole volume).

7. Incubate the above mixture of human blood and dengue virus for 30 minutes at $37^{\circ} \mathrm{C}$ water bath

\section{Feeding mosquitoes}

This procedure is almost identical to what have been described in the section for Plasmodium falciparum infections in mosquitoes. We assay the midgut infection at day 7 , and the salivary infection at day 14 after blood-feeding. All material that came in contact with the virus are treated first with $75 \%$ ethanol and then with $10 \%$ bleach.

\section{Assay the virus titer in mosquito tissue}

1. Two or three days before dissection of mosquito tissue, grow $\mathrm{C} 6 / 36$ cell in a 24 well plate such that the cell reach $80 \%$ confluency at the day when the assay is conducted;

2. Mosquitoes are anesthetized at $4^{\circ} \mathrm{C}$, sacrificed and surfaced sterile by soaking them in $75 \%$ ethanol for 1 minute. Then mosquitoes were washed with sterile water twice before dissection of midgut or salivary gland under the dissecting microscope. From this step, all the 
procedure below needs to be conducted in a sterile environment such as a biological safety cabinet. These tissues are transferred to a tube containing $150 \mu \mathrm{l}$ media and homogenized with a Kontes pellet pestle motor for 90 seconds;

3. Make a 1:100 dilution by adding $10 \mu \mathrm{l}$ of the homogenate into $990 \mu \mathrm{l}$ media;

4. Make further 1: $10,1: 100$ and 1:1000 dilution with the medium in the 96 well plate;

5. Remove the media in the 24 well plate, and add $100 \mu \mathrm{l}$ of each of the above four dilutions to each corresponding well;

6. Shake the plate slowly for 15 minutes at the room temperature, then incubate for 45 minutes at $5 \% \mathrm{CO}_{2}$ and $37^{\circ} \mathrm{C}$;

7. Add $1 \mathrm{ml}$ of methycellulose overlay (1\%) to each well;

8. Incubate plates at $37^{\circ} \mathrm{C}$ with $5 \% \mathrm{CO}_{2}$ for 5 days;

9. The steps from here on do not require a sterile environment but as with any other pathogen care should be taken at all times. Discard methycellulose overlay from each plate and blot to remove excess media

10. Add $1 \mathrm{ml}$ of methanol/acetone fixative $(1: 1)$ to each well. Keep at $4^{\circ} \mathrm{C}$ for $1 \mathrm{hr}$;

11. Pour off the fixative, and wash once with $1 \mathrm{X}$ PBS;

12. Make $1: 1000$ dilution to the primary antibody against the virus with $5 \%$ blotto;

13. Add $200 \mu \mathrm{l}$ of diluted hyperimmune fluid to each well, incubate at $37^{\circ} \mathrm{C}$ for $1 \mathrm{hr}$;

14. Remove hyperimmune fluid and wash plate with 1 X PBS

15. Prepare a 1:1000 dilution of goat anti-mouse conjugate (KPL Cat\# 074-1806) in 5\% blotto (5g powdered skim milk in $100 \mathrm{ml}$ of $1 \mathrm{X}$ PBS), and then add $200 \mu \mathrm{l}$ to each well, and incubate at $37^{\circ} \mathrm{C}$ for $1 \mathrm{hr}$;

16. Prepare substrate as follows: add 1 tablet of 3'-Diaminobenzidine terrahydrochloride (Sigma Cat\# D5905) in $20 \mathrm{ml}$ of 1 X PBS, after dissolved, and then add $8 \mu$ of $30 \%$ hydrogen peroxidase

17. Add $200 \mu \mathrm{l}$ of the above substrate to each well. Let stand at room temperature for 10 minutes

18. Remove substrate and stop reaction by adding $1 \mathrm{ml}$ of distilled water to each well

19. Pour off water and blot plates to dry

20. Count the virus particle 